Talarolutins A-D: Meroterpenoids from an Endophytic Fungal Isolate of Talaromyces minioluteus

Graphical Abstract

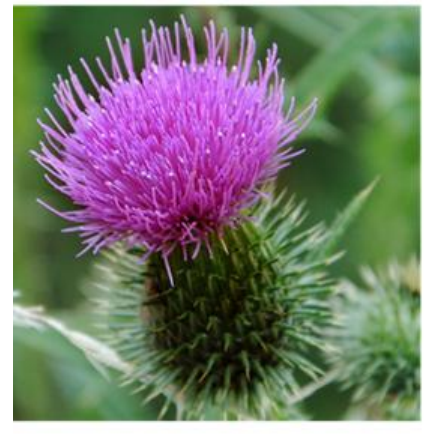

Silybum marianum

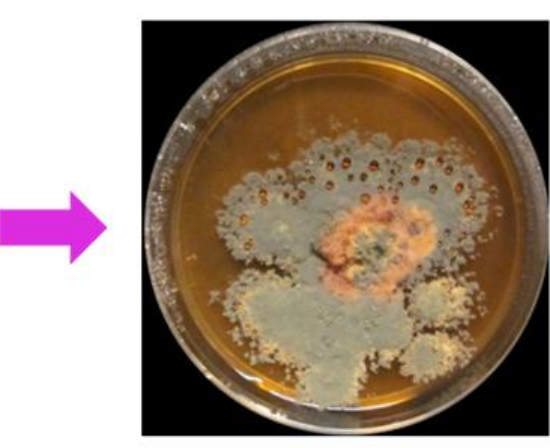

Talaromyces minioluteus

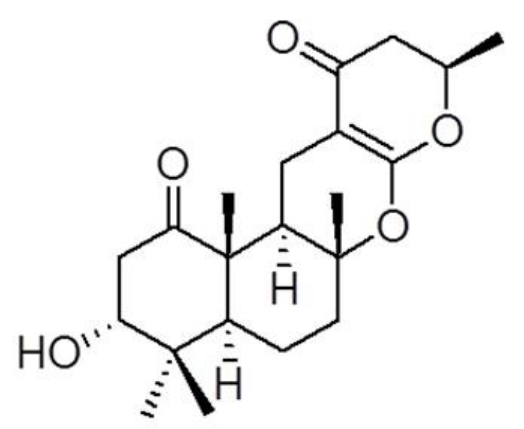

Talarolutin A 


\title{
Talarolutins A-D: Meroterpenoids from an Endophytic Fungal Isolate of Talaromyces minioluteus
}

\author{
Amninder Kaur ${ }^{\mathrm{a}}$, Huzefa A. Raja ${ }^{\mathrm{a}}$, Dale C. Swenson ${ }^{\mathrm{b}}$, Rajesh Agarwal ${ }^{\mathrm{c}}$, Gagan Deep ${ }^{\mathrm{c}}$, Joseph O. \\ Falkinham III $^{\mathrm{d}}$, and Nicholas H. Oberlies ${ }^{\mathrm{a}, *}$ \\ ${ }^{\mathrm{a}}$ Department of Chemistry and Biochemistry, University of North Carolina at Greensboro, \\ Greensboro, North Carolina 27402, USA \\ ${ }^{\mathrm{b}}$ Department of Chemistry, University of Iowa, Iowa City, IA 52242, USA \\ ${ }^{\mathrm{c}}$ Department of Pharmaceutical Sciences, Skaggs School of Pharmacy and Pharmaceutical \\ Sciences, University of Colorado Denver, Aurora, CO 80045, United States \\ ${ }^{\mathrm{d}}$ Department of Biological Sciences, Virginia Polytechnic Institute and State University, \\ Blacksburg, VA 24061, United States
}

* Corresponding author. Tel.: +1 3363345474.

E-mail address: nicholas_oberlies@uncg.edu (N.H. Oberlies). 


\section{Abstract}

Four meroterpenoids [talarolutins A-D] and one known compound [purpurquinone A] were characterized from an endophytic fungal isolate of Talaromyces minioluteus (G413), which was obtained from the leaves of the medicinal plant milk thistle [Silybum marianum (L.) Gaertn. (Asteraceae)]. The structures of talarolutins A-D were determined by the analysis of various NMR and MS techniques. The relative and absolute configuration of talarolutins A was determined by X-ray diffraction analysis. A combination of NOESY data and comparisons of ECD spectra were employed to assign the relative and absolute configuration of the other analogues. Talarolutins B-D were tested for cytotoxicity against human prostate carcinoma (PC3) cell line, antimicrobial activity, and induction of quinone reductase; no notable bioactivity was observed in any assay.

Keywords:

Meroterpenoid

Fungal endophyte

Talaromyces minioluteus

Milk thistle

Silybum marianum

Asteraceae 


\section{Introduction}

Plant-based secondary metabolites (primarily flavonolignans) from the medicinal herb milk thistle [Silybum marianum (L.) Gaertn. (Asteraceae)] have been studied extensively (Althagafy et al., 2013; Davis-Searles et al., 2005; Graf et al., 2007; Gufford et al., 2014; Napolitano et al., 2013; Polyak et al., 2010; Sy-Cordero et al., 2013). Recent studies that have explored the chemical and fungal diversity of endophytes associated with this plant have also yielded interesting results (El-Elimat et al., 2014b; Figueroa et al., 2014; Raja et al., 2015). In continuation of these investigations in search of new and/or biologically active natural products, an endophytic fungal isolate of Talaromyces minioluteus (G413), which was isolated from the leaves of milk thistle, was subjected to natural products chemistry techniques to yield four new meroterpenoids (Fig. 1), named here as talarolutins A-D (1-4), and one known compound, purpurquinone A (5) (Wang et al., 2011). Structurally diverse meroterpenoids with antimicrobial, antiviral, antitumor, immunomodulatory, and phytotoxic effects have been reported previously from various fungal sources (Geris and Simpson, 2009). Thus, compounds 2-4 were examined for biological activity in three assays, including cytotoxicity against a human prostate carcinoma (PC-3) cell line, antimicrobial activity, and induction of quinone reductase, but were all inactive.

\section{Results and discussion}

Talarolutin A (1) had the molecular formula $\mathrm{C}_{21} \mathrm{H}_{30} \mathrm{O}_{5}$, yielding an index of hydrogen deficiency of seven. Signals for five methyl groups (four singlets and one doublet), two oxygenated methines, and a series of aliphatic protons, including five methylene and two methine units, were observed in the ${ }^{1} \mathrm{H}$ NMR spectrum of $\mathbf{1}$ (Fig. S1, Supporting information; Table 1). In addition to the signals expected for these structural features, the ${ }^{13} \mathrm{C}$ NMR spectrum 
showed resonances for three quaternary and four non-protonated $s p^{2}$-hybridized carbons (Fig. S2; Table 2). The sesquiterpenoid-derived portion of $\mathbf{1}$ was constructed by the analysis of COSY, HSQC, and HMBC NMR data (Tables 1, 2, and S1). The upfield shifted methyl singlets, $\mathrm{H}_{3}-14$ $\left(\delta_{\mathrm{H}} 1.08,3 \mathrm{H}\right)$ and $\mathrm{H}_{3}-13\left(\delta_{\mathrm{H}} 1.02,3 \mathrm{H}\right)$, showed common $\mathrm{HMBC}$ correlations to an oxygenated carbon, C-3 $\left(\delta_{\mathrm{C}} 80.0\right)$, a quaternary carbon, C-4 $\left(\delta_{\mathrm{C}} 38.4\right)$, and C-5 $\left(\delta_{\mathrm{C}} 51.4\right)$. Further HMBC correlations from $\mathrm{H}-3\left(\delta_{\mathrm{H}} 3.88\right.$, br s) to a ketone carbonyl, $\mathrm{C}-1\left(\delta_{\mathrm{C}} 211.5\right)$ and $\mathrm{C}-5$, as well as, COSY correlations to $\mathrm{H}_{2}-2\left(\delta_{\mathrm{H}} 3.35, \mathrm{dd}, J=13.5,3.2 \mathrm{~Hz}\right.$ and 2.22 , dd, $\left.J=13.5,3.7 \mathrm{~Hz}, 2 \mathrm{H}\right)$ were observed. These data, in conjunction with $\mathrm{HMBC}$ correlations from methyl singlet $\mathrm{H}_{3}-15$ $\left(\delta_{\mathrm{H}} 1.24,3 \mathrm{H}\right)$ to $\mathrm{C}-1, \mathrm{C}-5, \mathrm{C}-9\left(\delta_{\mathrm{C}} 44.6\right)$, and quaternary carbon, $\mathrm{C}-10\left(\delta_{\mathrm{C}} 51.7\right)$, supported the presence of a cyclohexanone ring system. COSY NMR data identified a spin system $\mathrm{H}-5 / \mathrm{H}_{2}-$ 6/ $\mathrm{H}_{2}-7$ (Fig. S3), including two methylene units $\left(\delta_{\mathrm{H}} 1.69\right.$ and $1.50,2 \mathrm{H}$, for $\mathrm{H}_{2}-6 ; \delta_{\mathrm{H}} 2.04$ and $1.66,2 \mathrm{H}$, for $\left.\mathrm{H}_{2}-7\right)$. HMBC correlations from methyl protons, $\mathrm{H}_{3}-12\left(\delta_{\mathrm{H}} 1.26, \mathrm{~s}, 3 \mathrm{H}\right)$ to $\mathrm{C}-7\left(\delta_{\mathrm{C}}\right.$ 39.7), an oxygenated quaternary carbon, C-8 $\left(\delta_{\mathrm{C}} 83.4\right)$, and C-9 completed the decalin portion of the ring system of $\mathbf{1}$.

To complete the structural assignments of $\mathbf{1}, \mathrm{HMBC}$ correlations from $\mathrm{H}_{2}-11(\delta 2.96$, dd, $J=15.5,4.5 \mathrm{~Hz}$ and $1.91, \mathrm{dd}, J=15.5,12.7 \mathrm{~Hz}, 2 \mathrm{H})$ to C-8, C-9, C-10, olefinic carbons, C-1' $\left(\delta_{\mathrm{C}}\right.$ $168.4)$ and $\mathrm{C}-2^{\prime}\left(\delta_{\mathrm{C}} 91.1\right)$, and ketone carbonyl carbon, $\mathrm{C}-3^{\prime}\left(\delta_{\mathrm{C}} 191.2\right)$ appended the $\alpha, \beta$ unsaturated carbonyl unit to the bicyclic ring, thereby securing the attachment of C-11 to C-2'. The placement of a methylene unit, $\mathrm{H}_{2}-4^{\prime}\left(\delta_{\mathrm{H}} 2.48, \mathrm{dd}, J=16.9,14.0 \mathrm{~Hz}\right.$ and $\delta 2.35, \mathrm{dd}, J=16.9$, 3.2 $\mathrm{Hz}, 2 \mathrm{H})$, alpha to the ketone (C-3') was supported by HMBC correlations from $\mathrm{H}_{2}-4^{\prime}$ to $\mathrm{C}-2^{\prime}$ and C-3'. Multiplicity of $\mathrm{H}_{2}-4^{\prime}$, COSY NMR data, and additional HMBC correlations from $\mathrm{H}_{2}-4^{\prime}$ to $\mathrm{C}-5^{\prime}\left(\delta_{\mathrm{C}} 75.8\right)$ and $\mathrm{C}-6^{\prime}\left(\delta_{\mathrm{C}} 20.7\right)$ enabled the identification of the spin system, $\mathrm{H}_{2}-4^{\prime} / \mathrm{H}-5^{\prime} / \mathrm{H}_{3}-$ $6^{\prime}$, including the methyl group $\left(\delta_{\mathrm{H}} 1.43, \mathrm{~d}, J=6.3 \mathrm{~Hz}, 3 \mathrm{H}\right.$, for $\left.\mathrm{H}_{3}-6^{\prime}\right)$. Although an HMBC 
correlation from $\mathrm{H}-5^{\prime}\left(\delta_{\mathrm{H}} 4.57\right.$, dqd, $\left.J=14.0,6.3,3.2 \mathrm{~Hz}\right)$ to C-1' was not observed, the chemical shifts of C-1' and C-5' were consistent with an ether linkage between the two carbons, completing the modified pyranone-type ring system. A second ether linkage between carbons C8 and $\mathrm{C}-1^{\prime}$ accounted for the last remaining unsaturation, as well as the significant downfield chemical shift of $\mathrm{C}-1^{\prime}\left(\delta_{\mathrm{C}} 168.4\right)$. Attempts to assign the absolute configuration of $\mathbf{1}$ using Mosher's method resulted in degradation of the compound (Hoye et al., 2007). Fortunately, Xray diffraction analysis of a crystal obtained during the course of these studies not only confirmed the structure (Fig. 2), but also enabled the unambiguous assignment of the absolute configuration of 1 by employing the Flack parameter [F = 0.01 (18)] (Parsons and Flack, 2004).

The molecular formula of talarolutin B (2) was determined to be $\mathrm{C}_{21} \mathrm{H}_{32} \mathrm{O}_{5}$ (index of hydrogen deficiency of six) on the basis of HRESIMS data. The ${ }^{1} \mathrm{H}$ and ${ }^{13} \mathrm{C}$ NMR spectra of 2 (Figs. S4-S5; Tables 1-2) closely resembled those of $\mathbf{1}$. However, an additional oxygenated methine signal $\left(\delta_{\mathrm{C}} / \delta_{\mathrm{H}} 72.1 / 3.70\right.$ for $\left.\mathrm{H}-1\right)$ was observed in the NMR spectra of 2 that replaced the ketone carbonyl carbon observed in the ${ }^{13} \mathrm{C}$ NMR spectrum of $\mathbf{1}\left(\delta_{\mathrm{C}} 211.5\right.$ for C-1). These changes were consistent with the reduction of the carbonyl group at position C-1 to a secondary alcohol in $\mathbf{2}$ and accounted for the only key difference in the structure of talarolutin B (2), including one less degree of unsaturation. The small $J$-values observed for $\mathrm{H}-1$, resulting in a broad peak in the ${ }^{1} \mathrm{H}$ NMR spectrum (Fig. S4) supported the axial orientation of the hydroxy group. NOESY correlations between $\mathrm{H}-1$ and $\mathrm{H}_{3}-15 / \mathrm{H}_{3}-14\left(\delta_{\mathrm{H}} 0.83\right.$; overlapping signals) as well as between $\mathrm{H}-3, \mathrm{H}_{3}-14\left(\delta_{\mathrm{H}} 0.83\right)$, and $\mathrm{H}_{3}-13\left(\delta_{\mathrm{H}} 1.01\right)$ were also consistent with a 1, 3diaxial orientation for the hydroxy groups in $\mathbf{2}$. Assuming identical relative and absolute configuration at the in-common asymmetric centers between $\mathbf{1}$ and $\mathbf{2}$ (based on biosynthetic 
origins), C-1 was assigned the $S$-configuration by analysis of the proton coupling constants and NOESY NMR data (Fig. S6).

Inspection of the ${ }^{1} \mathrm{H}$ NMR spectrum (Fig. S7, Table 1) of talarolutin C (3) showed signals corresponding to the structural features similar to those observed for $\mathbf{1}$ and $\mathbf{2}$. The presence of a pair of coupled doublets $\left(\delta_{\mathrm{H}} 3.48, \mathrm{~d}, J=3.3 \mathrm{~Hz}\right.$ for $\mathrm{H}-2$ and $\delta_{\mathrm{H}} 3.27, \mathrm{~d}, J=3.3 \mathrm{~Hz}$ for $\left.\mathrm{H}-3\right)$, characteristic of epoxide protons in the ${ }^{1} \mathrm{H}$ NMR spectrum of $\mathbf{3}$, accounted for one of the key differences. Corresponding carbon signals $\left(\delta_{\mathrm{C}} 54.5\right.$ for C-2 and $\delta_{\mathrm{C}} 64.0$ for C-3) were also observed in the ${ }^{13} \mathrm{C}$ NMR spectrum (Fig. S8, Table 2). The position of the C-2/C-3 epoxide group was supported by HMBC correlations from $\mathrm{H}-2$ to $\mathrm{C}-1\left(\delta_{\mathrm{C}} 202.7\right)$ and $\mathrm{C}-10\left(\delta_{\mathrm{C}} 56.9\right)$, as well as from H-3 to C-1, C-4 $\left(\delta_{\mathrm{C}} 37.7\right), \mathrm{C}-5\left(\delta_{\mathrm{C}} 76.7\right)$, and C-14 $\left(\delta_{\mathrm{C}} 23.4\right)$. A NOESY correlation between H-2 and H-3 suggested a syn-epoxide moiety, and an additional correlation between H-2 and $\mathrm{H}_{3}-15\left(\delta_{\mathrm{H}} 1.23\right)$ placed these protons on the same face of the six-membered ring system. Additionally, another difference between $\mathbf{1}$ and $\mathbf{3}$ was oxygenation at C-5 in $\mathbf{3}$ relative to $\mathbf{1}$, resulting in a downfield-shift of C-5 $\left(\delta_{\mathrm{C}} 76.7\right)$ in $\mathbf{3}$ relative to $\mathbf{1}\left(\delta_{\mathrm{C}} 51.4\right)$ and the appearance of an additional hydroxy group $\left(\delta_{\mathrm{H}} 2.68\right.$ for $\left.5-\mathrm{OH}\right)$ at the ring junction; the HRESIMS data $[\mathrm{m} / \mathrm{z}$ $\left.377.1942(\mathrm{M}+\mathrm{H})^{+}\right]$were consistent with the molecular formula $\left(\mathrm{C}_{21} \mathrm{H}_{28} \mathrm{O}_{6}\right)$ of talarolutin $\mathrm{C}(3)$, including an extra oxygen moiety relative to the formula of 1. NOESY correlations between H- $6_{\alpha}$ $\left(\delta_{\mathrm{H}} 1.75\right), \mathrm{H}_{3}-13\left(\delta_{\mathrm{H}} 1.29\right)$, and 5-OH, as well as from methylene proton, $\mathrm{H}-6_{\beta}\left(\delta_{\mathrm{H}} 1.60\right)$ to pseudo-axially oriented methyl groups, $\mathrm{H}_{3}-15, \mathrm{H}_{3}-14\left(\delta_{\mathrm{H}} 1.27\right)$, and $\mathrm{H}_{3}-12\left(\delta_{\mathrm{H}} 1.25\right)$ supported the trans-ring junction for terpene-derived bicyclic ring system (Fig. S6); while not definitive, the absence of NOESY correlations between 5-OH and $\mathrm{H}_{3}-15$ were consistent with this assignment. The remaining asymmetric centers that were common with $\mathbf{1}$ and $\mathbf{2}$ were assigned analogous absolute configurations, as discussed previously. 
In the ${ }^{1} \mathrm{H}$ and ${ }^{13} \mathrm{C}$ NMR spectra (Fig. S9-S10, Tables 1-2) of talarolutin D (4), the epoxide signals observed in $\mathbf{3}$ were replaced by resonances characteristic of a double bond $\left(\delta_{\mathrm{C}} / \delta_{\mathrm{H}}\right.$ 124.2/5.76, d, $J=10.3$ and $\delta_{\mathrm{C}} / \delta_{\mathrm{H}} 150.7 / 6.17, \mathrm{~d}, J=10.3$ for C-2/H-2 and C-3/H-3, respectively). The molecular formula of $\mathbf{4}$ was determined to be $\mathrm{C}_{21} \mathrm{H}_{28} \mathrm{O}_{5}$ (eight unsaturations), which was consistent with such a substitution. The remaining structural features were similar to $\mathbf{3}$ and since no new asymmetric centers were generated, an analogous relative configuration was proposed for $\mathbf{4}$. A SciFinder search showed compounds $\mathbf{3}$ and $\mathbf{4}$ to be a part of an industrial catalogue. However, lack of reported NMR data as well as absence of relative and absolute configuration assignment did not allow unambiguous identification of these compounds. Therefore, $\mathbf{3}$ and $\mathbf{4}$ are considered new natural products and have been fully characterized in this report. The experimental ECD spectra (Fig. 3) for 1-4 showed a comparable trend supporting the assignment of all talarolutin analogues to the same enantiomeric series.

As with previous research on compounds isolated from endophytes of milk thistle (Raja et al., 2015), the compounds $2-\mathbf{4}$ were evaluated for cytotoxicity against the human prostate carcinoma (PC-3) cell line but all were inactive $\left(\mathrm{IC}_{50}\right.$ values $\left.>25 \mu \mathrm{M}\right)$. They were also examined in a suite of antimicrobial assays, but did not show any effects (MIC values $>100 \mu \mathrm{g} / \mathrm{mL}$ ) against Staphylococcus aureus, Escherichia coli, Mycobacterium smegmatis, Candida albicans, and Aspergillus niger. The structural features of talarolutins bore close resemblance to recently reported marine natural products, penicillipyrones A and B (Liao et al., 2014). The latter of these was reported to show significant induction of quinone reductase. Therefore, compounds 2-4 were also tested for biological activity in this assay but were found to be ineffective at the highest concentration tested $(25 \mu \mathrm{M})$. Due to low sample amounts, compounds $\mathbf{1}$ and $\mathbf{5}$ were not evaluated for any biological activity in various assays. Compound $\mathbf{5}$ was originally isolated from 
Penicillium purpurogenum and tested for bioactivity against influenza A virus (H1N1) but was found to be inactive (Wang et al., 2011).

\section{Conclusion}

Examination of an endophytic fungal isolate of milk thistle resulted in isolation of four new natural products from T. minioluteus. Biosynthetically, these compounds appear to be assembled by a combination of terpene-derived farnesyl moiety and a pyrone unit (Liao et al., 2014), and there is a growing interest in the biosynthesis of meroterpenoids due to their hybrid terpene and polyketide origins (Itoh et al., 2010). Although inactive in a few available assays, the new compounds append to only a handful of other reports of the chemistry from T. minioluteus (Ngokpol et al., 2015; Yilmaz et al., 2014). The mycology of the genus Talaromyces, in addition to a brief summary of the few secondary metabolites reported from $T$. minioluteus, has been reviewed recently (Yilmaz et al., 2014). Miniolins A-C were reported from an epigenetically modified culture of $P$. minioluteum (now T. minioluteus) (Tang et al., 2015). Our ongoing studies of endophytes of milk thistle and other medicinal plants have also yielded a suite of secondary metabolites belonging to structurally diverse classes (Bussey et al., 2015; El-Elimat et al., 2014b; Figueroa et al., 2014; Kaur et al., 2015; Raja et al., 2015). These observations support the overall goal of exploring this ecological group for new secondary metabolites.

\section{Experimental}

\subsection{General experimental procedures}


NMR experiments were conducted using an Agilent-700 and/or JEOL ECS-400 spectrometers (700 or $400 \mathrm{MHz}$ for ${ }^{1} \mathrm{H}$ NMR and 175 or $100 \mathrm{MHz}$ for ${ }^{13} \mathrm{C}$ NMR; Agilent Technologies, Santa Clara, CA, USA; JEOL Ltd., Tokyo, Japan). HRESIMS data were collected using an electrospray ionization (ESI) source coupled to a Q-ToF Premier mass spectrometer (Waters Corp., Milford, MA, USA) or a LTQ Orbitrap XL system (Thermo Fisher Scientific, San Jose, CA, USA) in positive and/or negative ionization modes by direct injection or via a liquid chromatography/autosampler system comprised of Acquity UPLC system (Waters Corp.). A CombiFlash Rf system using a RediSep Rf Si-gel Gold column (both from Teledyne-Isco, Lincoln, NE, USA) was employed for normal phase flash column chromatography (cc). HPLC separations were performed utilizing a Varian Prostar HPLC system (Varian Inc., Palo Alto, CA, USA) equipped with Prostar 210 pumps and a Prostar 335 photodiode array detector, using Galaxie Chromatography Workstation software (version 1.9.3.2, Varian Inc.). Kinetex $\mathrm{C}_{18}$ (Phenomenex, Torrance, CA, USA; $5 \mu \mathrm{m}$; columns of dimensions $250 \times 21.2 \mathrm{~mm}$ and $250 \times 4.6$

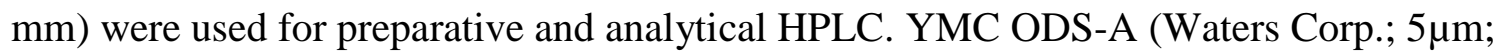
columns of dimensions $250 \times 10 \mathrm{~mm}$ and $250 \times 4.6 \mathrm{~mm}$ ) columns were used for semipreparative and analytical HPLC in selected cases. For UPLC analysis, a BEH $\mathrm{C}_{18}$ (Waters Corp.; $1.7 \mu \mathrm{m} ; 50 \times 2.1 \mathrm{~mm}$ ) column was used. Optical rotation data were acquired on a Rudolph Research Autopol III polarimeter (Rudolph Research Analytical, Flanders, NJ, USA). ECD data were collected using an Olis DSM 17 CD spectrophotometer (Olis, Bogard, GA, USA). UV data were obtained using a Varian Cary 100 Bio UV-vis spectrophotometer (Varian Medical Systems, Palo Alto, CA, USA). IR data were collected using PerkinElmer Spectrum One with Universal ATR attachment (PerkinElmer, Inc., Waltham, MA, USA). The solvents were obtained from Fisher Scientific. 


\subsection{Isolation and identification of fungal strain}

Fungal strain G413 was isolated as an endophyte from healthy surface sterilized leaves of milk thistle using procedures outlined previously (Figueroa et al., 2014). Based on morphology, it was evident that strain G413 belonged to Talaromyces minioluteus (Dierckx) Samson, Yilmaz, Frisvad, and Seifert (Yilmaz et al., 2014) (Fig. S11). Micromorphology of conidiophore and conidia agrees well with the original protologue presented recently in a polyphasic taxonomic study of the genus Talaromyces (Yilmaz et al., 2014).

For molecular identification of strain G413, two gene regions were sequenced. First, the nuclear ribosomal internal transcribed spacer region (ITS) was sequenced as it has been identified as a barcoding marker for fungi (Schoch et al., 2012). In addition to the ITS region, sequence data was obtained from the RNA polymerase II largest subunit gene (RPBI). The RPB1 region has been utilized in phylogenetic studies of subgenus Biverticillium (Samson et al., 2011). DNA extraction, PCR amplification, and phylogenetic analysis were performed following methods summarized earlier (El-Elimat et al., 2013; Figueroa et al., 2014). The RPB1 region was amplified using primers RPB1-F1843 and RPB1-R3096 and PCR protocols outlined by Houbraken and Samson (2011) with some modifications. The first PCR reaction was carried out in $25 \mu \mathrm{L}$ containing $3 \mu \mathrm{L}$ template DNA, $2.5 \mu \mathrm{L}$ BSA (New England BioLabs Inc), $2.5 \mu \mathrm{L} 50 \%$ DMSO (Sigma), and $1 \mu \mathrm{L}$ of each $10 \mu \mathrm{M}$ forward (RPB1-F1843) and reverse (RPB1-R3096) primer. The rest of the volume was made up to $25 \mu \mathrm{L}$ by adding molecular biology grade $\mathrm{H}_{2} \mathrm{O}$ from Fisher Scientific. After the first PCR, 1.5 $\mu \mathrm{L}$ PCR product was used to run a second PCR using the same protocol as the first PCR reaction. The PCR products were then run on an ethidium bromide-stained 1\% agarose gel (Fisher Scientific) along with a $1 \mathrm{~kb}$ DNA ladder (Promega) to estimate the size of the amplified band. PCR products were finally purified using a 
Wizard SV Gel and PCR Clean-up System. Bidirectional Sanger sequencing of the purified PCR products was performed at Eurofins Genomics (http://www.operon.com/default.aspx) using BigDye Terminator v3.1 cycle sequencing. Sequences are edited using Sequencher 5.2.3 (Gene Codes Corp.). BLAST searches were then performed against the NCBI GenBank database separately using both the ITS region as well as the RPB1 gene. Based on the ITS region BLAST search, against the TYPE database (Schoch et al., 2014), the closest hits were T. minioluteus (CBS 642.68; from TYPE material) GenBank NR_121527.1; Identities = 561/575 (98\%); Gaps = 12/572 (2\%), Penicillium samsonii (CBS 137.84) GenBank JN899369; Identities = 562/571 (98\%); Gaps = 9/571 (1\%), and Penicillium purogenum var. rubrisclerotium $(\mathrm{CBS} 270.35)$ GenBank JN899381; Identities = 560/571 (98\%); Gaps = 10/571 (1\%). Similar results were obtained using the RPB1 region. According to Samson and colleagues (Samson et al., 2011; Yilmaz et al., 2014) $P$. samsonii and $P$. purogenum var. rubrisclerotium are synonymous with $T$. minioluteus. The RBPI sequences from the top BLAST search based on sequence similarity were downloaded and incorporated into an alignment with $R P B 1$ sequence from $\mathrm{G} 413$ for a maximum likelihood (ML) analysis using RAxML (Stamatakis, 2006). Results from both the BLAST search and ML analysis suggests that strain G413 can be identified as T. minioluteus [Pezizomycotina; leotiomyceta; Eurotiomycetes; Eurotiomycetidae; Eurotiales; Trichocomaceae]; the sequence from strain G413 forms a strong clade with $99 \%$ bootstrap statistical support with T. minioluteus, P. purogenum var. rubrisclerotium, and P. samsonii (Fig. S12). The fungal culture is maintained at the University of North Carolina at Greensboro, Department of Chemistry and Biochemistry Fungal Culture Collection, and a voucher specimen (G413) is deposited there. The sequence data was deposited in the GenBank (ITS: KM215653; RPB1: KU363961). 


\subsection{Fermentation and extraction}

For extractions, fungal cultures were grown on rice using procedures detailed previously (El-Elimat et al., 2014a). Briefly, seed cultures grown on malt extract agar (MEA; Difco) medium were excised from the leading edge of the colony and transferred to a liquid medium containing $2 \%$ soy peptone, $2 \%$ dextrose and $1 \%$ yeast extract (YESD). Following incubation (7 d) at $22{ }^{\circ} \mathrm{C}$ with agitation, the culture was used to inoculate rice media $(50 \mathrm{~mL})$ prepared using rice and twice the volume of rice with $\mathrm{H}_{2} \mathrm{O}$ in a $250 \mathrm{~mL}$ Erlenmeyer flask. This was incubated at $22{ }^{\circ} \mathrm{C}$ until the cultures showed good growth (14-21 d). To produce larger amounts of material, three $250 \mathrm{~mL}$ Erlenmeyer flasks were inoculated in an identical manner using one seed culture for each flask.

To each solid-substrate fermentation culture (G413) grown on rice (three flasks), $\mathrm{CH}_{3} \mathrm{OH}: \mathrm{CHCl}_{3}(60 \mathrm{~mL}, 1: 1 \mathrm{v} / \mathrm{v})$ was added. The culture was chopped into small pieces with a spatula and shaken overnight ( $\sim 125 \mathrm{rpm}$ at rt) using a rotary shaker. The sample was vacuum filtered, and the remaining residues were washed with small volumes of $\mathrm{CH}_{3} \mathrm{OH}: \mathrm{CHCl}_{3}(1: 1$ $\mathrm{v} / \mathrm{v})$. The filtrates from the three flasks were combined and $\mathrm{CHCl}_{3}: \mathrm{H}_{2} \mathrm{O}(540 \mathrm{~mL}, 1: 1 \mathrm{v} / \mathrm{v})$ were added, followed by stirring for $30 \mathrm{~min}$. The organic layer was collected and evaporated to dryness under reduced pressure. The organic extract was further partitioned between $\mathrm{CH}_{3} \mathrm{OH}: \mathrm{CH}_{3} \mathrm{CN}(300 \mathrm{~mL}, 1: 1 \mathrm{v} / \mathrm{v})$ and hexanes $(300 \mathrm{~mL})$. The $\mathrm{CH}_{3} \mathrm{OH}: \mathrm{CH}_{3} \mathrm{CN}$ layer was evaporated to dryness in vacuum to yield crude extract $(802 \mathrm{mg})$.

\subsection{Isolation}

The organic extract $(802 \mathrm{mg})$ was dissolved in a minimum amount of $\mathrm{CHCl}_{3}: \mathrm{CH}_{3} \mathrm{OH}(1: 1$ v/v), adsorbed onto Celite 545, and subjected to flash normal-phase CC using a gradient solvent 
system of hexane: $\mathrm{CHCl}_{3}: \mathrm{CH}_{3} \mathrm{OH}$ at $30 \mathrm{~mL} / \mathrm{min}$ flow rate and 61 column volumes over $34.1 \mathrm{~min}$ to afford three fractions. Fraction $2(70 \mathrm{mg})$ was subjected to preparative RP HPLC [Kinetex- $\mathrm{C}_{18}$ column, linear gradient elution using $\mathrm{CH}_{3} \mathrm{CN}: \mathrm{H}_{2} \mathrm{O}$ (containing $0.1 \% \mathrm{HCOOH}$ ): $40-80 \% \mathrm{CH}_{3} \mathrm{CN}$ for $20 \mathrm{~min} ; \lambda=210$ and $254 \mathrm{~nm} ; 21.2 \mathrm{~mL} / \mathrm{min}]$ to yield $4\left(16.8 \mathrm{mg} ; \mathrm{t}_{\mathrm{R}}=5.5 \mathrm{~min}\right)$ and a mixture of 3 and $4\left(14.6 \mathrm{mg} ; t_{R}=6.0 \mathrm{~min}\right)$. The mixture of $\mathbf{3}$ and $\mathbf{4}$ was then purified using prep RP HPLC [Kinetex- $\mathrm{C}_{18}$ column, isocratic $\mathrm{CH}_{3} \mathrm{CN}: \mathrm{H}_{2} \mathrm{O}$ (containing 0.1\% $\mathrm{HCOOH}$ ), 35:65 v/v, 21.2 $\mathrm{mL} / \mathrm{min}]$ affording pure talarolutin $\mathrm{C}\left(\mathbf{3}, 8.5 \mathrm{mg}, \mathrm{t}_{\mathrm{R}}=11.0 \mathrm{~min}\right)$ and talarolutin $\mathrm{D}\left(\mathbf{4} ; 3.0 \mathrm{mg} ; \mathrm{t}_{\mathrm{R}}=\right.$ 9.5 min). Preparative RP HPLC [Kinetex- $\mathrm{C}_{18}$ column, gradient elution using $\mathrm{CH}_{3} \mathrm{CN}: \mathrm{H}_{2} \mathrm{O}$ (containing $0.1 \% \mathrm{HCOOH}$ ): $40-60 \% \mathrm{CH}_{3} \mathrm{CN}$ for $20 \mathrm{~min} ; 60-80 \% \mathrm{CH}_{3} \mathrm{CN}$ for $10 \mathrm{~min} ; \lambda=210$ and $254 \mathrm{~nm} ; 21.2 \mathrm{~mL} / \mathrm{min}]$ of fraction $3(480 \mathrm{mg})$ resulted in isolation of $4\left(14.7 \mathrm{mg} ; \mathrm{t}_{\mathrm{R}}=6.0\right.$ $\min )$ and mixtures of $\mathbf{1}\left(12.0 \mathrm{mg} ; \mathrm{t}_{\mathrm{R}}=6.5 \mathrm{~min}\right), \mathbf{5}\left(11.7 \mathrm{mg} ; \mathrm{t}_{\mathrm{R}}=7.0 \mathrm{~min}\right)$, and $\mathbf{2}\left(19.5 \mathrm{mg} ; \mathrm{t}_{\mathrm{R}}=\right.$ $9.5 \mathrm{~min}$ ). Compounds $\mathbf{1}, \mathbf{2}$, and $\mathbf{5}$ were further purified using prep RP HPLC [Kinetex- $\mathrm{C}_{18}$ column, $21.2 \mathrm{~mL} / \mathrm{min}]$ affording pure talarolutin $\mathrm{A}\left[\mathbf{1}, 1.7 \mathrm{mg}, \mathrm{t}_{\mathrm{R}}=11.5 \mathrm{~min}\right.$; isocratic $\mathrm{CH}_{3} \mathrm{CN}: \mathrm{H}_{2} \mathrm{O}$ (containing 0.1\% $\mathrm{HCOOH}$ ), 35:65 v/v], talarolutin $\mathrm{B}\left[2,6.9 \mathrm{mg}, \mathrm{t}_{\mathrm{R}}=12.5 \mathrm{~min}\right.$; isocratic $\mathrm{CH}_{3} \mathrm{CN}: \mathrm{H}_{2} \mathrm{O}$ (containing 0.1\% $\mathrm{HCOOH}$ ) 35:65 v/v], and purpurquinone A [5, $1.2 \mathrm{mg}$, $\mathrm{t}_{\mathrm{R}}=12.5 \mathrm{~min}$; isocratic $\mathrm{CH}_{3} \mathrm{CN}: \mathrm{H}_{2} \mathrm{O}$ (containing 0.1\% HCOOH) 40:60 v/v]. The HRMS and ${ }^{1} \mathrm{H}$ NMR data for 5 were fully consistent with those reported in literature (Wang et al., 2011). To achieve $\geq 95 \%$ pure sample of $\mathbf{2}$, an additional purification step employing semi-preparative RP HPLC [YMC- $\mathrm{C}_{18}$ column, isocratic $\mathrm{CH}_{3} \mathrm{CN}: \mathrm{H}_{2} \mathrm{O}$ (containing 0.1\% $\mathrm{HCOOH}$ ), 40:60 v/v; $\lambda=210$ and $254 \mathrm{~nm} ; 3 \mathrm{~mL} / \mathrm{min}$ ] was carried out to yield pure talarolutin $B\left(2,5.7 \mathrm{mg}, \mathrm{t}_{\mathrm{R}}=29.0 \mathrm{~min}\right)$.

\subsection{Talarolutin A (1)}



$(-12), 289(+71) \mathrm{nm}$; for ${ }^{1} \mathrm{H},{ }^{13} \mathrm{C}$, and HMBC NMR spectroscopic data, see Tables 1,2 , and S1 respectively; HRESIMS $m / z$ 363.2151 $[\mathrm{M}+\mathrm{H}]^{+}$(calcd. for $\mathrm{C}_{21} \mathrm{H}_{31} \mathrm{O}_{5}, 363.2166$ ).

\subsection{Talarolutin B (2)}

Colorless powder ; $[\alpha]_{\mathrm{D}}^{23}=+200\left(c=0.11, \mathrm{CH}_{3} \mathrm{OH}\right)$; UV/Vis $\left(\mathrm{CH}_{3} \mathrm{OH}\right) \lambda_{\max }(\log \varepsilon) 208$ (3.0), $271(3.7) \mathrm{nm}$; IR (diamond) $v_{\max } 2971,1581,1423,1052,1033 \mathrm{~cm}^{-1}$; ECD (183 $\mu \mathrm{M}$, $\left.\mathrm{CH}_{3} \mathrm{OH}\right) \lambda_{\max }(\Delta \varepsilon) 266(-9), 287(+75) \mathrm{nm}$; for ${ }^{1} \mathrm{H},{ }^{13} \mathrm{C}$, and HMBC NMR spectroscopic data, see Tables 1, 2, and S1 respectively; HRESIMS $m / z 365.2306[\mathrm{M}+\mathrm{H}]^{+}$(calcd. for $\mathrm{C}_{21} \mathrm{H}_{33} \mathrm{O}_{5}$, 365.2322).

4.7. Talarolutin C (3)

Colorless powder ; $[\alpha]_{\mathrm{D}}^{23}=+124\left(c=0.15, \mathrm{CH}_{3} \mathrm{OH}\right) ; \mathrm{UV} / \mathrm{Vis}\left(\mathrm{CH}_{3} \mathrm{OH}\right) \lambda_{\max }(\log \varepsilon) 211$ (2.6), 271 (3.6) nm; IR (diamond) $v_{\max } 2998,1587,1422,1186,1139,1052 \mathrm{~cm}^{-1}$; ECD (177 $\mu \mathrm{M}$, $\left.\mathrm{CH}_{3} \mathrm{OH}\right) \lambda_{\max }(\Delta \varepsilon) 266(-8), 288(+38), 328(-3) \mathrm{nm}$; for ${ }^{1} \mathrm{H},{ }^{13} \mathrm{C}$, and HMBC NMR spectroscopic data, see Tables 1, 2, and S1 respectively; HRESIMS m/z $377.1942[\mathrm{M}+\mathrm{H}]^{+}$ (calcd. for $\mathrm{C}_{21} \mathrm{H}_{29} \mathrm{O}_{6}, 377.1959$ ).

\subsection{Talarolutin D (4)}

Colorless oil ; $[\alpha]_{\mathrm{D}}^{25}=+214\left(c=0.24, \mathrm{CH}_{3} \mathrm{OH}\right) ; \mathrm{UV} / \mathrm{Vis}\left(\mathrm{CH}_{3} \mathrm{OH}\right) \lambda_{\max }(\log \varepsilon) 227$ (3.6), 272 (3.7) nm; IR (diamond) $v_{\max } 1689,1586,1421,1186 \mathrm{~cm}^{-1}$; ECD $\left(185 \mu \mathrm{M}, \mathrm{CH}_{3} \mathrm{OH}\right) \lambda_{\max }(\Delta \varepsilon)$ $238(+23), 288(+53), 331(-12) \mathrm{nm}$; for ${ }^{1} \mathrm{H},{ }^{13} \mathrm{C}$, and HMBC NMR spectroscopic data, see 
Tables 1, 2, and S1 respectively; HRESIMS $m / z, 361.1997[\mathrm{M}+\mathrm{H}]^{+}$(calcd. for $\mathrm{C}_{21} \mathrm{H}_{29} \mathrm{O}_{5}$, 361.2010).

\subsection{X-ray diffraction analysis of talarolutin A (1)}

A specimen of $\mathrm{C}_{21} \mathrm{H}_{30} \mathrm{O}_{5}$, approximate dimensions $0.005 \mathrm{~mm} \times 0.010 \mathrm{~mm} \times 0.090 \mathrm{~mm}$, was used for the X-ray crystallographic analysis. The X-ray intensity data were measured. Intensity data were collected at $150 \mathrm{~K}$ on a D8 goniostat equipped with a Bruker PHOTON100 CMOS detector at Beamline 11.3.1 at the Advanced Light Source (Lawrence Berkeley National Laboratory) using synchrotron radiation tuned to $\lambda=1.2399 \AA$. For data collection, frames were measured for a duration of 1 -s at $0.5^{\circ}$ intervals of $\omega$ with a maximum $2 \theta$ value of $\sim 60^{\circ}$. The total exposure time was 0.73 hours. The frames were integrated with the Bruker SAINT software package using a narrow-frame algorithm. The integration of the data using a monoclinic unit cell yielded a total of 11510 reflections to a maximum $\theta$ angle of $50.93^{\circ}$ ( $0.80 \AA$ resolution), of which 3748 were independent (average redundancy 3.071 , completeness $=99.1 \%, \mathrm{R}_{\text {int }}=4.93 \%$, $\left.\mathrm{R}_{\text {sig }}=5.08 \%\right)$ and $3231(86.21 \%)$ were greater than $2 \sigma\left(\mathrm{F}^{2}\right)$. The final cell constants of $\underline{\mathrm{a}}=$ 13.0307(13) $\AA, \underline{b}=5.9960(6) \AA, \underline{c}=13.6512(13) \AA, \beta=118.418(5)^{\circ}$, volume $=938.07(16) \AA^{3}$, are based upon the refinement of the XYZ-centroids of 7139 reflections above $20 \sigma(\mathrm{I})$ with $5.920^{\circ}<2 \theta<96.37^{\circ}$. Data were corrected for absorption effects using the multi-scan method (SADABS). The ratio of minimum to maximum apparent transmission was 0.804 . The calculated minimum and maximum transmission coefficients (based on crystal size) are 0.9670 and 0.9980 . The final anisotropic full-matrix least-squares refinement on $\mathrm{F}^{2}$ with 244 variables converged at $\mathrm{R} 1=4.15 \%$, for the observed data and $\mathrm{wR} 2=10.03 \%$ for all data. The goodness-of-fit was 1.035. The largest peak in the final difference electron density synthesis was $0.204 \mathrm{e}^{-} / \AA^{3}$ and the 
largest hole was $-0.299 \mathrm{e}^{-} / \AA^{3}$ with an RMS deviation of $0.043 \mathrm{e}^{-} / \AA^{3}$. On the basis of the final model, the calculated density was $1.280 \mathrm{~g} / \mathrm{cm}^{3}$ and $\mathrm{F}(000), 390 \mathrm{e}^{-}$. Crystal data have been deposited with the Cambridge Crystallographic Data Centre and can be accessed using the deposition number, CCDC 1046537.

\subsection{Bioassays}

Human prostate carcinoma PC-3 cells were obtained from American Type Culture Collection (Manassas, VA) and cultured under ATCC recommended conditions. The effect of pure compounds on viability of PC-3 cells was determined by the methods described previously (Raja et al., 2015). Minimal inhibitory concentrations (MICs) of compounds 2-4 in antimicrobial assays were determined using the methods outlined previously (Ayers et al., 2012). For the quinone reductase assay, the commercially available NQO activity assay kit from Abcam (Cambridge, MA) was utilized exactly as recommended by the vendor.

\section{Acknowledgments}

This research was funded in part by a Biotechnology Research Grant (2011-BRG-1206) from the North Carolina Biotechnology Center. The researchers in Colorado were supported by a grant from the National Cancer Institute/National Institutes of Health (R01 CA102514). The highresolution mass spectrometry data were acquired in the Triad Mass Spectrometry Laboratory at the University of North Carolina at Greensboro. Crystallographic data were collected through the SCrALS (Service Crystallography at Advanced Light Source) program at Beamline 11.3.1 at the Advanced Light Source (ALS), Lawrence Berkeley National Laboratory. The ALS is supported by the U.S. Department of Energy, Office of Energy Sciences Materials Sciences Division, under 
contract DE-AC02-05CH11231.

\section{Appendix A. Supplementary data}

Supporting Information. ${ }^{1} \mathrm{H}$ NMR, ${ }^{13} \mathrm{C}$ NMR, and ECD spectra for compounds $\mathbf{1 - 4}$, images of the micromorphology of strain G413, the phylogram of the most likely tree, and X-ray diffraction analysis. This material is available free of charge via the Internet at (weblink). 


\section{References}

Althagafy, H. S., Meza-Aviña, M. E., Oberlies, N. H., Croatt, M. P., 2013. Mechanistic study of the biomimetic synthesis of flavonolignan diastereoisomers in milk thistle. J. Org. Chem. 78, 7594-7600.

Ayers, S., Ehrmann, B. M., Adcock, A. F., Kroll, D. J., Carcache de Blanco, E. J., Shen, Q., Swanson, S. M., Falkinham, J. O., Wani, M. C., Mitchell, S. M., 2012. Peptaibols from two unidentified fungi of the order Hypocreales with cytotoxic, antibiotic, and anthelmintic activities. J. Pept. Sci. 18, 500-510. Bussey, R. O., Kaur, A., Todd, D. A., Egan, J. M., El-Elimat, T., Graf, T. N., Raja, H. A., Oberlies, N. H., Cech, N. B., 2015. Comparison of the chemistry and diversity of endophytes isolated from wild-harvested and greenhouse-cultivated yerba mansa (Anemopsis californica). Phytochem. Lett. 11, 202-208.

Davis-Searles, P. R., Nakanishi, Y., Kim, N.-C., Graf, T. N., Oberlies, N. H., Wani, M. C., Wall, M. E., Agarwal, R., Kroll, D. J., 2005. Milk thistle and prostate cancer: differential effects of pure flavonolignans from Silybum marianum on antiproliferative end points in human prostate carcinoma cells. Cancer Res. 65, 4448-4457.

El-Elimat, T., Figueroa, M., Raja, H. A., Graf, T. N., Adcock, A. F., Kroll, D. J., Day, C. S., Wani, M. C., Pearce, C. J., Oberlies, N. H., 2013. Benzoquinones and terphenyl compounds as phosphodiesterase-4B inhibitors from a fungus of the order Chaetothyriales (MSX 47445). J. Nat. Prod. 76, 382-387.

El-Elimat, T., Raja, H. A., Figueroa, M., Falkinham, J. O., Oberlies, N. H., 2014a. Isochromenones, isobenzofuranone, and tetrahydronaphthalenes produced by Paraphoma radicina, a fungus isolated from a freshwater habitat. Phytochemistry 104, 114-120. El-Elimat, T., Raja, H. A., Graf, T. N., Faeth, S. H., Cech, N. B., Oberlies, N. H., $2014 b$. Flavonolignans from Aspergillus iizukae, a fungal endophyte of milk thistle (Silybum marianum). J. Nat. Prod. 77, 193-199.

Figueroa, M., Jarmusch, A. K., Raja, H. A., El-Elimat, T., Kavanaugh, J. S., Horswill, A. R., Cooks, R. G., Cech, N. B., Oberlies, N. H., 2014. Polyhydroxyanthraquinones as quorum sensing inhibitors from the guttates of Penicillium restrictum and their analysis by desorption electrospray ionization mass spectrometry. J. Nat. Prod. 77, 1351-1358.

Geris, R., Simpson, T. J., 2009. Meroterpenoids produced by fungi. Nat. Prod. Rep. 26, 10631094.

Graf, T. N., Wani, M. C., Agarwal, R., Kroll, D. J., Oberlies, N. H., 2007. Gram-scale purification of flavonolignan diastereoisomers from Silybum marianum (Milk Thistle) extract in support of preclinical in vivo studies for prostate cancer chemoprevention. Planta Med. 73, 1495. Gufford, B. T., Chen, G., Lazarus, P., Graf, T. N., Oberlies, N. H., Paine, M. F., 2014. Identification of diet-derived constituents as potent inhibitors of intestinal glucuronidation. Drug Metab. Dispos. 42, 1675-1683.

Houbraken, J., Samson, R. A., 2011. Phylogeny of Penicillium and the segregation of Trichocomaceae into three families. Stud. Mycol., 1-51. Hoye, T. R., Jeffrey, C. S., Shao, F., 2007. Mosher ester analysis for the determination of absolute configuration of stereogenic (chiral) carbinol carbons. Nat. Protoc. 2, 2451-2458. 
Itoh, T., Tokunaga, K., Matsuda, Y., Fujii, I., Abe, I., Ebizuka, Y., Kushiro, T., 2010. Reconstitution of a fungal meroterpenoid biosynthesis reveals the involvement of a novel family of terpene cyclases. Nat. Chem. 2, 858-864.

Kaur, A., Raja, H. A., Deep, G., Agarwal, R., Oberlies, N. H., 2015. Pannorin B, a new naphthopyrone from an endophytic fungal isolate of Penicillium sp. Magn. Reson. Chem. Liao, L., Lee, J.-H., You, M., Choi, T. J., Park, W., Lee, S. K., Oh, D.-C., Oh, K.-B., Shin, J., 2014. Penicillipyrones A and B, meroterpenoids from a marine-derived Penicillium sp. fungus. J. Nat. Prod. 77, 406-410. Napolitano, J. G., Lankin, D. C., Graf, T. N., Friesen, J. B., Chen, S.-N., McAlpine, J. B., Oberlies, N. H., Pauli, G. F., 2013. HiFSA fingerprinting applied to isomers with near-identical NMR spectra: the silybin/isosilybin case. J. Org. Chem. 78, 2827-2839.

Ngokpol, S., Suwakulsiri, W., Sureram, S., Lirdprapamongkol, K., Aree, T., Wiyakrutta, S., Mahidol, C., Ruchirawat, S., Kittakoop, P., 2015. Drimane sesquiterpene-conjugated amino acids from a marine isolate of the fungus Talaromyces minioluteus (Penicillium minioluteum). Mar. drugs 13, 3567-3580.

Parsons, S., Flack, H., 2004. Precise absolute-structure determination in light-atom crystals. Acta Crystallogr. Sect. A 60, 61-61.

Polyak, S. J., Morishima, C., Lohmann, V., Pal, S., Lee, D. Y., Liu, Y., Graf, T. N., Oberlies, N. H., 2010. Identification of hepatoprotective flavonolignans from silymarin. P. Natl. Acad. Sci. USA 107, 5995-5999.

Raja, H. A., Kaur, A., El-Elimat, T., Figueroa, M., Kumar, R., Deep, G., Agarwal, R., Faeth, S. H., Cech, N. B., Oberlies, N. H., 2015. Phylogenetic and chemical diversity of fungal endophytes isolated from Silybum marianum (L) Gaertn.(milk thistle). Mycology 6, 8-27.

Samson, R., Yilmaz, N., Houbraken, J., Spierenburg, H., Seifert, K., Peterson, S., Varga, J., Frisvad, J. C., 2011. Phylogeny and nomenclature of the genus Talaromyces and taxa accommodated in Penicillium subgenus Biverticillium. Stud. Mycol. 70, 159-183.

Schoch, C. L., Robbertse, B., Robert, V., Vu, D., Cardinali, G., Irinyi, L., Meyer, W., Nilsson, R. H., Hughes, K., Miller, A. N., Kirk, P. M., Abarenkov, K., Aime, M. C., Ariyawansa, H. A., Bidartondo, M., Boekhout, T., Buyck, B., Cai, Q., Chen, J., Crespo, A., Crous, P. W., Damm, U., De Beer, Z. W., Dentinger, B. T. M., Divakar, P. K., Dueñas, M., Feau, N., Fliegerova, K., García, M. A., Ge, Z.-W., Griffith, G. W., Groenewald, J. Z., Groenewald, M., Grube, M., Gryzenhout, M., Gueidan, C., Guo, L., Hambleton, S., Hamelin, R., Hansen, K., Hofstetter, V., Hong, S.-B., Houbraken, J., Hyde, K. D., Inderbitzin, P., Johnston, P. R., Karunarathna, S. C., Kõljalg, U., Kovács, G. M., Kraichak, E., Krizsan, K., Kurtzman, C. P., Larsson, K.-H., Leavitt, S., Letcher, P. M., Liimatainen, K., Liu, J.-K., Lodge, D. J., Jennifer Luangsa-ard, J., Lumbsch, H. T., Maharachchikumbura, S. S. N., Manamgoda, D., Martín, M. P., Minnis, A. M., Moncalvo, J.-M., Mulè, G., Nakasone, K. K., Niskanen, T., Olariaga, I., Papp, T., Petkovits, T., Pino-Bodas, R., Powell, M. J., Raja, H. A., Redecker, D., Sarmiento-Ramirez, J. M., Seifert, K. A., Shrestha, B., Stenroos, S., Stielow, B., Suh, S.-O., Tanaka, K., Tedersoo, L., Telleria, M. T., Udayanga, D., Untereiner, W. A., Diéguez Uribeondo, J., Subbarao, K. V., Vágvölgyi, C., Visagie, C., Voigt, K., Walker, D. M., Weir, B. S., Weiß, M., Wijayawardene, N. N., Wingfield, M. J., Xu, J. P., Yang, Z. L., Zhang, N., Zhuang, W.-Y., Federhen, S., 2014. Finding needles in haystacks: linking scientific names, reference specimens and molecular data for Fungi. Database 2014. Schoch, C. L., Seifert, K. A., Huhndorf, S., Robert, V., Spouge, J. L., Levesque, C. A., Chen, W., Fungal Barcoding, C., 2012. Nuclear ribosomal internal transcribed spacer (ITS) region as a universal DNA barcode marker for Fungi. Proc. Natl. Acad. Sci. USA 109, 6241-6246. 
Stamatakis, A., 2006. RAxML-VI-HPC: Maximum likelihood-based phylogenetic analyses with thousands of taxa and mixed models. Bioinformatics 22, 2688-2690.

Sy-Cordero, A. A., Graf, T. N., Runyon, S. P., Wani, M. C., Kroll, D. J., Agarwal, R., Brantley, S. J., Paine, M. F., Polyak, S. J., Oberlies, N. H., 2013. Enhanced bioactivity of silybin B methylation products. Bioorg. Med. Chem. 21, 742-747.

Tang, H.-Y., Zhang, Q., Gao, Y.-Q., Zhang, A.-L., Gao, J.-M., 2015. Miniolins A-C, novel isomeric furanones induced by epigenetic manipulation of Penicillium minioluteum. RCS Adv. 5, 2185-2190.

Wang, H., Wang, Y., Wang, W., Fu, P., Liu, P., Zhu, W., 2011. Anti-influenza virus polyketides from the acid-tolerant fungus Penicillium purpurogenum JS03-21. J. Nat. Prod. 74, 2014-2018. Yilmaz, N., Visagie, C. M., Houbraken, J., Frisvad, J. C., Samson, R. A., 2014. Polyphasic taxonomy of the genus Talaromyces. Stud. Mycol. 78, 175-341. 


\section{List of Figures}
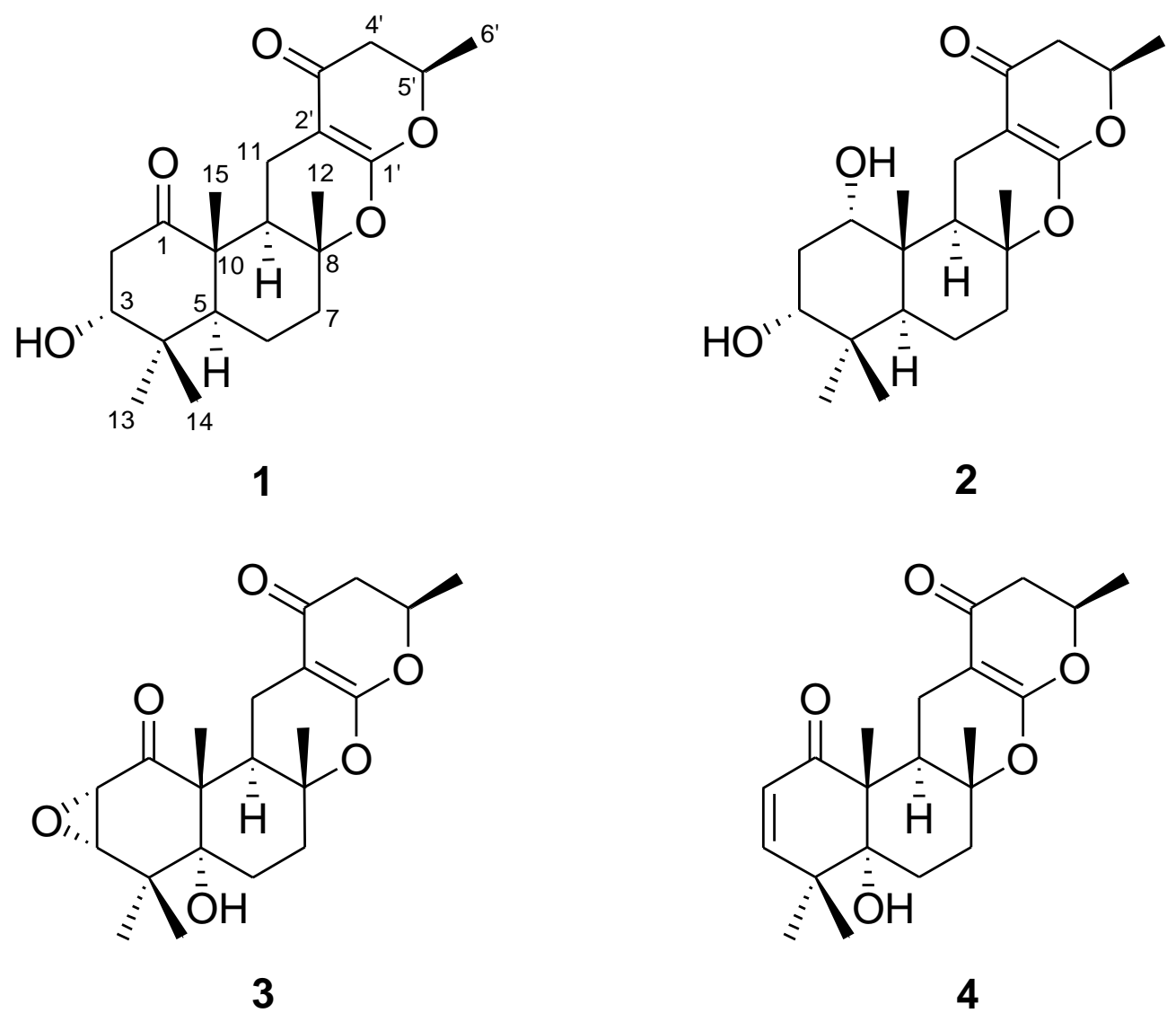

3

4<smiles>C/C=C/C1=CC2=CC(=O)[C@@](C)(OC(=O)c3c(C)cc(O)cc3O)C(=O)[C@]2(O)C(O)O1</smiles>

5

Fig.1. Structures of talarolutins A-D (1-4) and purpurquinone A (5). 


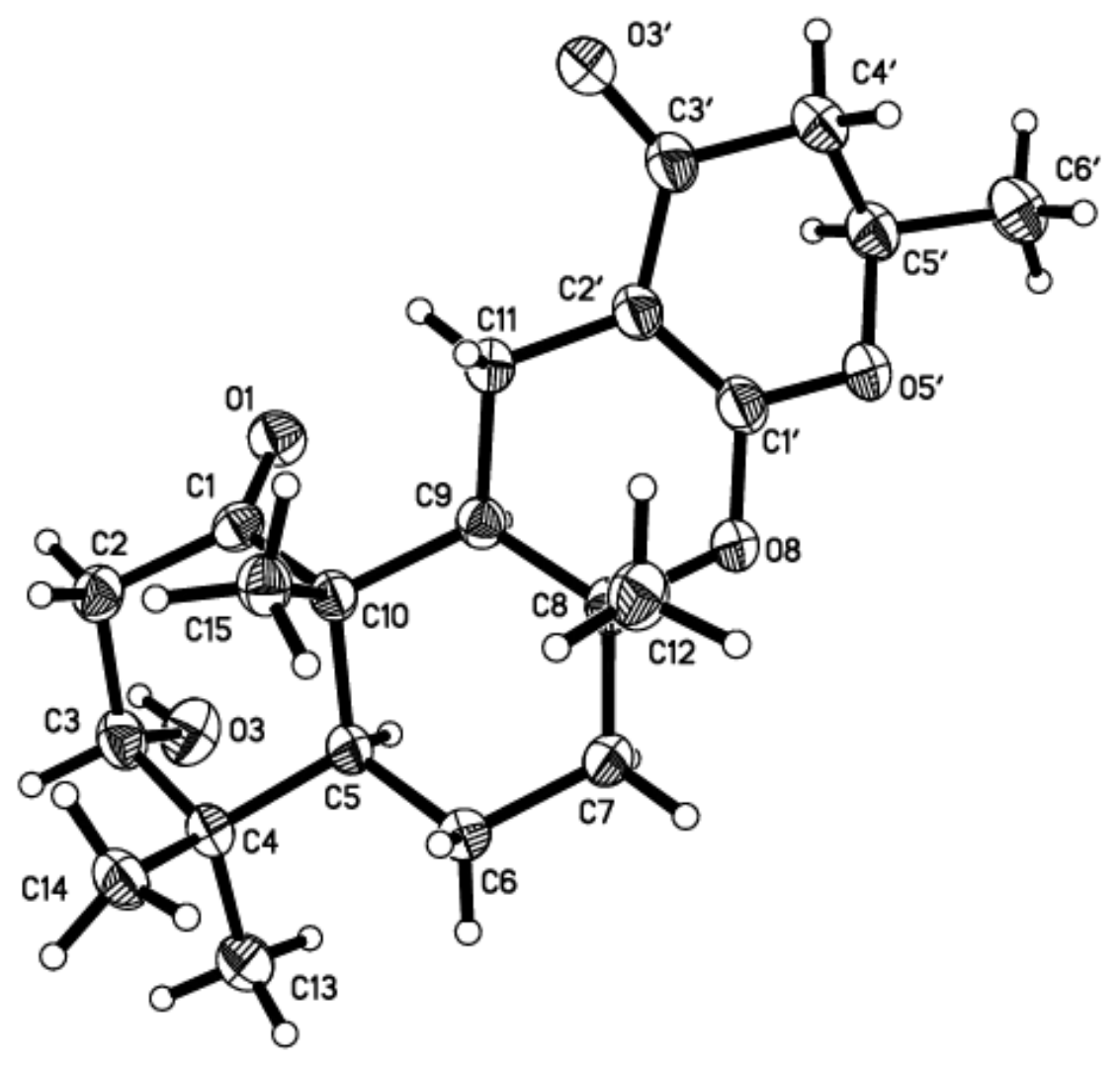

Fig. 2. ORTEP drawing of the molecular structure of $\mathbf{1 .}$ 


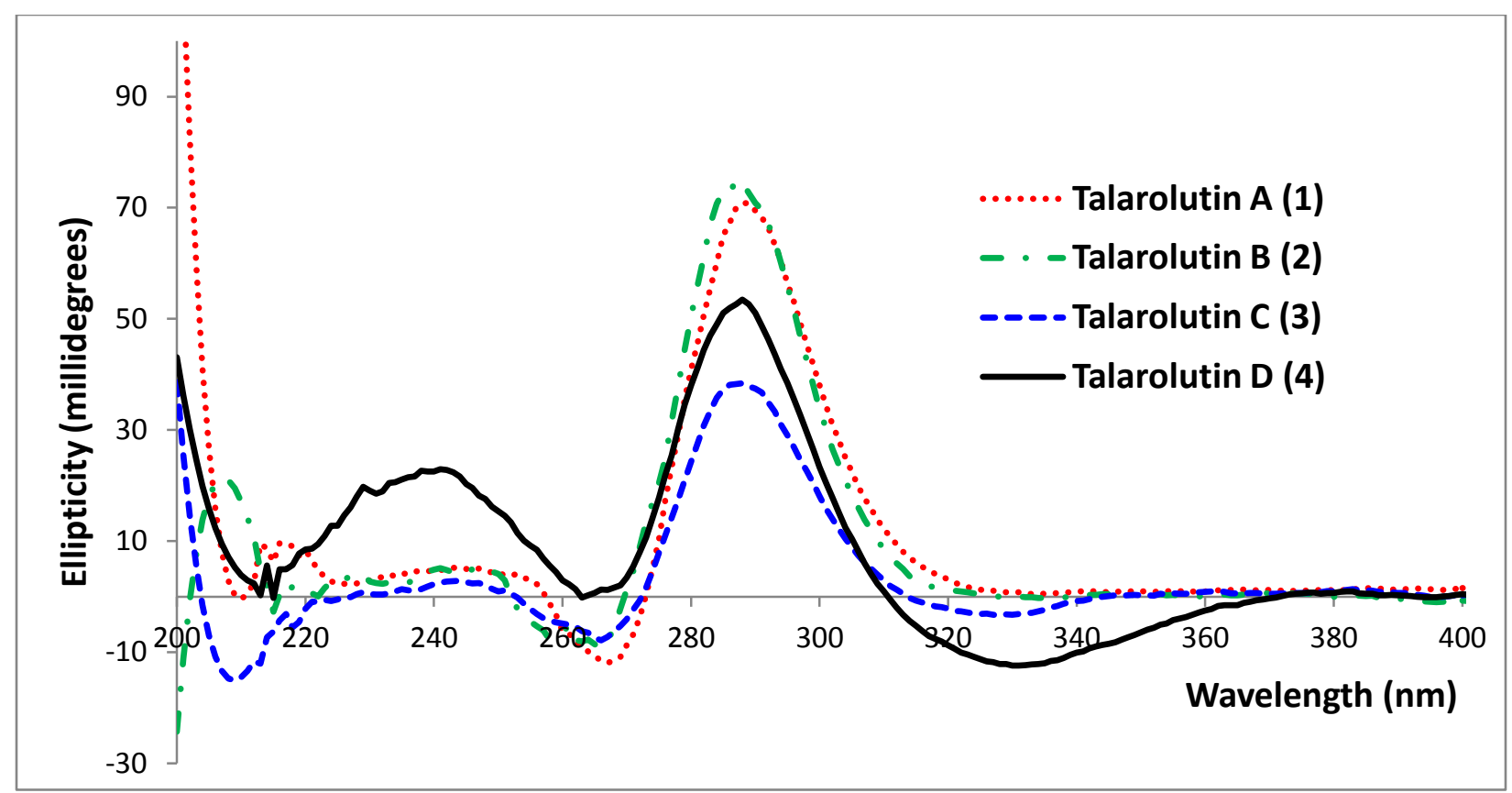

Fig. 3. Experimental ECD spectra of 1-4. 
Table 1

${ }^{1} \mathrm{H}$ NMR spectroscopic data (400 MHz) for $\mathbf{1}-\mathbf{4}$ in $\mathrm{CDCl}_{3}$.

\begin{tabular}{|c|c|c|c|c|}
\hline \multirow[t]{2}{*}{$\#$} & 1 & 2 & 3 & 4 \\
\hline & $\delta_{\mathrm{H}}($ mult., $J$ ) & $\delta_{\mathrm{H}}$ (mult., $J$ ) & $\delta_{\mathrm{H}}$ (mult., $J$ ) & $\delta_{\mathrm{H}}$ (mult., $J$ ) \\
\hline 1 & & 3.70 (br s) & & \\
\hline $2 \alpha$ & $3.35(\mathrm{dd}, 13.5,3.2)$ & $2.19(\mathrm{dt}, 13.5,2.5)$ & $3.48(\mathrm{~d}, 3.3)$ & $5.76(\mathrm{~d}, 10.3)$ \\
\hline $2 \beta$ & $2.22(\mathrm{dd}, 13.5,3.7)$ & $1.96(\mathrm{dt}, 13.5,2.7)$ & & \\
\hline 3 & $3.88($ br s) & $3.52($ br s $)$ & $3.27(\mathrm{~d}, 3.3)$ & $6.17(\mathrm{~d}, 10.3)$ \\
\hline 5 & $1.81(\mathrm{dd}, 12.7,2.0)$ & $1.78(\mathrm{dd}, 12.6,2.0)$ & & \\
\hline $6 \alpha$ & $1.69(\mathrm{~m})$ & $1.74(\mathrm{~m})$ & $1.75(\mathrm{dt}, 13.9,3.5)$ & $1.79(\mathrm{dd}, 14.4,3.6)$ \\
\hline $6 \beta$ & $1.50(\mathrm{~m})$ & $1.41(\mathrm{~m})$ & $1.60(\mathrm{~m})$ & $1.73(\mathrm{ddd}, 14.4,4.1,3.3)$ \\
\hline $7 \alpha$ & $2.04(\mathrm{~m})$ & $2.06(\mathrm{~m})$ & $2.21(\mathrm{~m})$ & $2.19(\mathrm{dt}, 4.9,14.1)$ \\
\hline $7 \beta$ & $1.66(\mathrm{~m})$ & $1.70(\mathrm{~m})$ & $1.70(\mathrm{dt}, 12.8,3.4)$ & $1.82(\mathrm{~m})$ \\
\hline 9 & $2.04(\mathrm{~m})$ & $2.21(\mathrm{dd}, 13.0,4.9)$ & $2.64(\mathrm{dd}, 12.8,4.5)$ & $2.60(\mathrm{dd}, 12.8,4.5)$ \\
\hline $11 \alpha$ & $2.96(\mathrm{dd}, 15.5,4.5)$ & $2.37(\mathrm{dd}, 15.2,4.9)$ & $3.04(\mathrm{dd}, 15.3,4.5)$ & $3.15(\mathrm{dd}, 15.5,4.5)$ \\
\hline $11 \beta$ & $1.91(\mathrm{dd}, 15.5,12.7)$ & $1.99(\mathrm{dd}, 15.2,13.0)$ & $1.98(\mathrm{dd}, 15.3,12.8)$ & $2.01(\mathrm{dd}, 15.5,12.8)$ \\
\hline 12 & $1.26(\mathrm{~s})$ & $1.25(\mathrm{~s})$ & $1.25(\mathrm{~s})$ & $1.33(\mathrm{~s})$ \\
\hline 13 & $1.02(\mathrm{~s})$ & $1.01(\mathrm{~s})$ & $1.29(\mathrm{~s})$ & $1.25(\mathrm{~s})$ \\
\hline 14 & $1.08(\mathrm{~s})$ & $0.83(\mathrm{~s})$ & $1.27(\mathrm{~s})$ & $1.13(\mathrm{~s})$ \\
\hline 15 & $1.24(\mathrm{~s})$ & $0.83(\mathrm{~s})$ & $1.23(\mathrm{~s})$ & $1.297(\mathrm{~s})$ \\
\hline $4^{\prime} \alpha$ & $2.48(\mathrm{dd}, 16.9,14.0)$ & $2.49(\mathrm{dd}, 16.8,14.0)$ & $2.48(\mathrm{dd}, 16.9,14.4)$ & $2.49(\mathrm{dd}, 16.9,14.0)$ \\
\hline $4^{\prime} \beta$ & $2.35(\mathrm{dd}, 16.9,3.2)$ & $2.32(\mathrm{dd}, 16.8,3.1)$ & $2.36(\mathrm{dd}, 16.9,2.9)$ & $2.36(\mathrm{dd}, 16.9,3.2)$ \\
\hline $5^{\prime}$ & $4.57(\mathrm{dqd}, 14.0,6.3,3.2)$ & $4.54(\mathrm{ddq}, 14.0,3.1,6.3)$ & $4.60(\mathrm{ddq}, 14.4,2.9,6.3)$ & $4.60(\mathrm{ddq}, 14.0,3.2,6.3)$ \\
\hline $6^{\prime}$ & $1.43(\mathrm{~d}, 6.3)$ & $1.42(\mathrm{~d}, 6.3)$ & $1.43(\mathrm{~d}, 6.3)$ & $1.44(\mathrm{~d}, 6.3)$ \\
\hline $3-\mathrm{OH}$ & 1.54 (br s) & & & \\
\hline $5-\mathrm{OH}$ & & & $2.68(\mathrm{br} \mathrm{d}, 2.0)$ & $1.44(\mathrm{~s})$ \\
\hline
\end{tabular}


Table 2

${ }^{13} \mathrm{C}$ NMR spectroscopic data (100 MHz) for $\mathbf{1 - 4}$ in $\mathrm{CDCl}_{3} .{ }^{\mathrm{a}}$

\begin{tabular}{lllll}
\hline$\#$ & $\mathbf{1}$ & $\mathbf{2}$ & $\mathbf{3}$ & $\mathbf{4}$ \\
\hline 1 & 211.5 & 72.1 & 202.7 & 203.0 \\
2 & 42.8 & 29.8 & 54.5 & 124.2 \\
3 & 80.0 & 77.8 & 64.0 & 150.7 \\
4 & 38.4 & 38.0 & 37.7 & 42.0 \\
5 & 51.4 & 42.3 & 76.7 & 78.4 \\
6 & 19.6 & 19.4 & 25.1 & 25.2 \\
7 & 39.7 & 40.0 & 31.9 & 32.8 \\
8 & 83.4 & 84.7 & 82.8 & 82.9 \\
9 & 44.6 & 44.5 & 38.7 & 38.7 \\
10 & 51.7 & 41.5 & 56.9 & 53.6 \\
11 & 17.1 & 15.3 & 17.8 & 17.7 \\
12 & 20.9 & 20.71 & 20.2 & 20.5 \\
13 & 27.7 & 28.5 & 23.8 & 24.0 \\
14 & 22.2 & 21.8 & 23.4 & 25.6 \\
15 & 14.5 & 15.6 & 16.2 & 18.6 \\
$1^{\prime}$ & 168.4 & 168.9 & 168.4 & 168.4 \\
$2^{\prime}$ & 91.1 & 90.5 & 91.1 & 91.5 \\
$3^{\prime}$ & 191.2 & 191.5 & 191.3 & 191.3 \\
$4^{\prime}$ & 42.9 & 42.7 & 42.8 & 42.8 \\
$5^{\prime}$ & 75.8 & 75.6 & 75.9 & 75.8 \\
$6^{\prime}$ & 20.7 & 20.67 & 20.6 & 20.6 \\
\hline a $\delta$ in ppm. & & & \\
\hline
\end{tabular}

